\title{
O grau zero da ficção: desmolduramento enunciativo em Delírio de Damasco
}

Fiction level zero: enunciative un-framing in Delírio de Damasco

\author{
El grado cero de la ficción: des-molduramiento enunciativo en Delírio de Damasc
}

Clarissa Loyola Comin*

\begin{abstract}
Resumo
O objetivo deste trabalho é refletir como se dá a experiência de leitura em Delírio de Damasco (2012), de Veronica Stigger. Para isso, levantaremos questões relacionadas à enunciação literária, servindo-nos da noção de desmolduramento enunciativo, que será explicitada e desenvolvida durante a análise com o suporte de conceitos como enunciado fictício e enunciado natural, ambos cunhados por Barbara Smith. Nossa hipótese é de que nesta obra temos uma linguagem sem contorno, desmoldurada, pois desprovida dos referenciais básicos de ancoragem narrativa (narrador, enredo, personagens). Assim, problematizando o abalo do lugar da enunciação literária em Delírio de Damasco, interessa-nos pensar de que modo este gesto afeta a posição do leitor: como se dá a passagem ruidosa do existente ao inexistente e quais as consequências desse movimento junto ao contínuo ininterrupto entre real e imaginário.
\end{abstract}

Palavras-chave: desmolduramento enunciativo, Veronica Stigger, Delírio de Damasco, Barbara Smith.

\begin{abstract}
This paper's aim is to reflect upon the reading experience that derives from Delírio de Damasco (2012), from Brazilian author Veronica Stigger. For such a reflection, we raise questions related to the literary enunciation, mainly through the notion of enunciative un-framing, which will be properly developed through our analysis with the support of concepts such as fictive utterance and natural utterance, both conceived by Barbara Smith. We start from the hypothesis that, in this particular work, we have a language without contours, un-framed, mainly because it is a language devoid of the basic elements that inform traditional narrative (narrator, plot, characters). Looking critically at this disturbance in the literary enunciation caused by Delírio de Damasco, we think through how this gesture affects the reader's position: how does the noisy transition between the existent and the inexistent take place and what are the consequences of that movement for the continuous stream between real and imaginary.
\end{abstract}

Keywords: enunciative unframing, Veronica Stigger, Delírio de Damasco, Barbara Smith.

\begin{abstract}
Resumen
El objetivo de este trabajo es el de reflejar cómo se da la experiencia de lectura en Delírio de Damasco (2012), de Veronica Stigger. Con tal intento, planteamos cuestiones relacionadas a la enunciación literaria, sirviéndonos de la noción de desenmarcamiento enunciativo, que será explicitada y desarrollada durante el análisis con el soporte de conceptos como enunciado ficticio y enunciado natural, ambos acuñados por Barbara Smith. Nuestra hipótesis es que, en esta obra, tenemos un lenguaje sin contorno, sin marco, pues se haya despojado de los referenciales básicos de un anclaje narrativo (narrador, trama, personajes). Así, problematizando el estremecimiento del lugar de la enunciación literaria en Delírio de Damasco, nos interesa pensar de qué modo tal gesto afecta la posición del lector: cómo se da el paso ruidoso de lo existente a lo inexistente; y cuáles son las consecuencias de ese movimiento junto al continuo ininterrumpido entre lo real y lo imaginario.
\end{abstract}

Palabras clave: des-enmarcamiento enunciativo, Veronica Stigger, Delírio de Damasco, Barbara Smith.

\footnotetext{
* Doutoranda na Universidade Federal do Paraná (UFPR), Curitiba, PR, Brasil. (Dorcid.org/0000-0002-0822-0505. E-mail: cominclarissa@gmail.com.
} 


\section{Literatura pós-autônoma}

Nem toda literatura é do gênero ou do tipo "fiç̧ão", mas há ficcionalidade em toda literatura.

Jacques Derrida

Josefina Ludmer, em um texto breve e especulativo, reflete sobre a ficção latino-americana dos anos 2000 e aponta para seu caráter de "escritas ou literaturas pós-autônomas" (Ludmer, 2013, p. 128). Tal noção, caracterizada como uma "escritura do presente", aponta para o borramento dos limites entre ficção e realidade, imiscuindo-se as duas instâncias, e levando esses textos a "se coloca[rem] fora e dentro, como numa posição diaspórica; estão fora, mas presos a seu interior. É como se estivessem em êxodo" (Ludmer, 2013, p. 128). Assim, a desestabilização do próprio gênero literário torna-se um traço constitutivo dessas escritas e prevalece a ambivalência de serem ao mesmo tempo ficção e realidade. São textos que questionam não apenas o caráter do literário, mas também implicam em uma remodelação do nosso entendimento de "realidade cotidiana". Ao fabricar o presente, o aqui e agora, através de gêneros do cotidiano - diário íntimo, reportagens jornalísticas e crônicas -, temos a representação da representação, pois "na realidade cotidiana, o sujeito e a realidade histórica não se opõem. Menos ainda literatura e história, ficção e realidade" (Ludmer, 2013, p. 130).

Nesse sentido, podemos pensar em uma espécie de contínuo entre realidade e ficção (realidadeficção, assim justapostas e equivalentes, como cunhou a autora), onde se entrevê uma gradação qualitativa entre os dois polos, posto que estes se retroalimentam e, no limite, se transbordam. Ao fim de sua argumentação, Ludmer constata, ainda que rapidamente, um dado relevante a respeito do amálgama discursivo, onde as literaturas pós-autônomas "entrariam em um meio (uma matéria) real-virtual, sem exterior, que é a imaginação pública; em tudo o que se produz e circula e nos invade e é social e privado e público e real" (Ludmer, 2013, p. 133), ou seja, a indiscernibilidade entre o público e o privado.

O texto de Ludmer é provocativo e desfia diversas pontas a partir das quais podemos trilhar diferentes percursos. Nesse sentido, perguntei-me como é possível apreender, em termos de matéria textual, a realidadeficção nos textos pós-autônomos? Uma porta de entrada parecem ser os novos modos de enunciação presentes nas literaturas pós-autônomas, ou seja, os novos modos de dizer eu na enunciação literária. O paradigma da ficção realista nos ensinou a distinguir os distintos modelos de vozes narrativas, a reconhecer o discurso direto, a montar o cenário e a mise-en-scène através das descrições. Mas o que acontece quando essas molduras convencionais são suprimidas e nos encontramos diante de um desmolduramento enunciativo?

Para trabalhar essa noção, fulcral para este artigo, tomaremos como base o texto da escritora contemporânea Veronica Stigger, Delírio de Damasco, onde essas questões se põem de modo contundente e inovador.

\section{Das pré-histórias à história}

Delírio de Damasco nos interessa a partir de duas vias: primeiro, porque joga amplamente com os limites entre realidade e ficção; segundo, porque subverte o lugar do autor enquanto responsável pela autoria do texto. Antes de abordarmos o livro em si, um breve recuo faz-se necessário. Em 2010, Stigger foi convidada pela curadoria da Mostra Sesc de Artes, em São Paulo, para participar com uma intervenção. A autora teria à sua disposição os tapumes que revestiam a unidade do Sesc 24 de Maio, à época em reforma, para preencher como quisesse. Assim, decidiu dar vazão às frases alheias de que vinha tomando nota há algum tempo. Stigger executou, em parceria com a artista plástica Edna Nogueira da Silva, a intervenção Pré-histórias - nome também de uma das seções que compõe outra obra sua, Os anões (2010) - deslocando o sentido geológico usual ao trazer a expressão para o campo do literário.

Chamá-las de pré-histórias aponta para um procedimento: as "histórias" ali dispostas, em estado embrionário, instigam o leitor a imaginar um enredo, ou, ainda, uma moldura. Assim, uma 
vez destacadas de seus respectivos contextos, o espectador-leitor é incumbido da tarefa de conferir às histórias seus contornos contextuais (quem disse o que para quem), ou seja, o espectador-leitor é demovido da posição passiva de quem apenas recebe o texto e é levado a lidar com o desmolduramento enunciativo. As imagens a seguir (Figura 1) reproduzem como foram apresentadas as pré-histórias na ocasião:
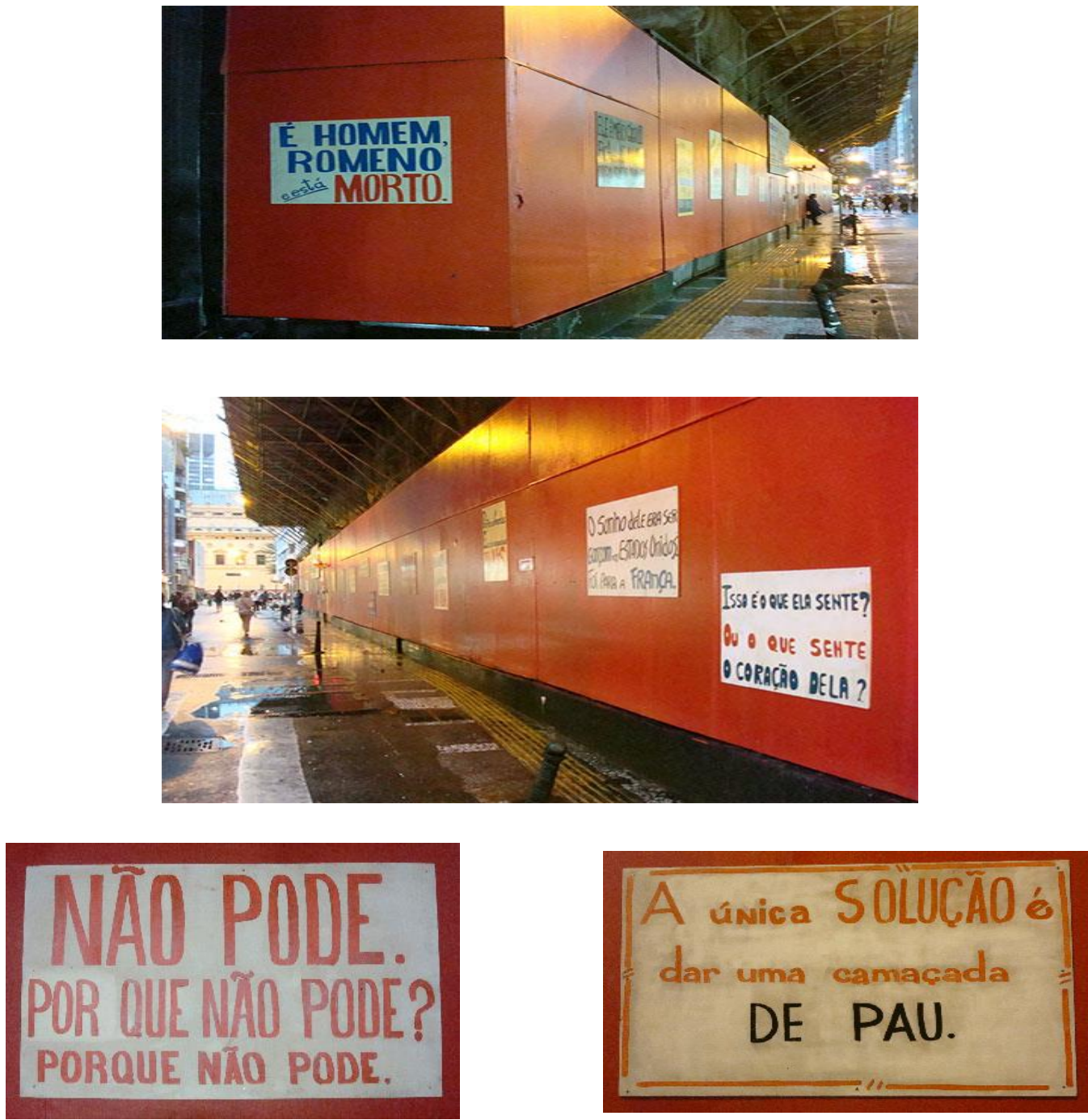

Figura 1 - Intervenção Pré-histórias na Mostra SESC das Artes em São Paulo.

Fonte: Stigger (2013).

Nesse contexto, estava em questão não apenas o que era lido, mas também o que era visto. É como se certos aspectos da enunciação - prosódia, entonação, timbre - tivessem sido substituídos pela materialidade plástica e pelo suporte gráfico entrevistos na escolha das cores, fontes e tamanhos dos escritos, pois nenhum deles é idêntico. Em vários cartazes percebe-se a adoção de uma estética mais caricata e de fácil reconhecimento, aquela dos anúncios de supermercado, o que reforça o caráter de exposição e espetacularização numa triangulação desejante entre o espectador, o emissor e o topos (o que se diz). Justamente por jogar com desejos, algumas frases, cujo conteúdo foi considerado mais ofensivo, ficaram de fora da exposição e figuram apenas na versão impressa publicada em 2012. Esse dado, que poderia passar desapercebido, corrobora o impasse que o desmolduramento enunciativo provoca. Se por um lado, em termos enunciativos-ficcionais, seria impossível atribuir 
autoria às frases de cunho sexual ou politicamente preconceituoso, por outro, o Sesc, enquanto instituição promotora, entreviu o risco de ser responsabilizado caso alguém se sentisse ofendido por alguma das declarações. Quer dizer, temos de forma manifesta a realidadeficção da qual falava Ludmer com o adendo de que as consequências oriundas desse amálgama extrapolariam o universo puramente ficcional.

Passando da exposição pública para sua versão impressa, que recebe o título Delírio de Damasco, temos uma obra que chama a atenção desde seu projeto gráfico. Uma caderneta em dimensões reduzidas, de aspecto artesanal, mínimo como suas pré-histórias. À primeira vista, o livro parece despretensioso: uma coletânea de frases feitas, colhidas de ouvido pelas ruas, como reforça a própria autora na quarta capa:

Delírio de Damasco é a reunião dessas frases ouvidas aqui e ali, numa espécie de arqueologia da linguagem do presente, em busca da poesia inesperada - dura ou terna, ingênua ou irônica - que pudesse haver em meio a nossos costumeiros diálogos sobre a tríade sangue, sexo e grana (Stigger, 2012).

Todavia, o que há de aparentemente inofensivo é, na verdade, uma estratégia. Dividido em cinco partes, Delírio de Damasco organiza-se de tal modo que as duas primeiras sessões, versando respectivamente sobre as díades comida-escatologia e dinheiro-relações amorosas, soam amenas com seus ditos espirituosos e divertidos (como as que figuraram na exposição do Sesc), firmando assim um pacto com o leitor. Nas sessões seguintes o tom jocoso se mantém mas passa a ser atravessado por frases que vão do preconceituoso ao criminoso:

Prefiro as gordas:

elas se empenham

mais (Stigger, 2012, p. 32).

Minha mãe rezava

para que eu não

namorasse uma negra (Stigger, 2012, p. 34).

Me diz uma coisa,

ele é débil mental

ou só feio mesmo? (Stigger, 2012, p. 50)

Um cara bacana.

Mas ele não é normal.

Se fosse, não dava o cu (Stigger, 2012, p. 59).

O incômodo se dá não apenas pela quebra do pacto de leitura firmado previamente, onde os ditos soavam amenos, mas porque revela-se um conflito com relação à autoria. Uma vez que a moldura nos é suprimida, a imputabilidade das frases torna-se conflituosa.

\section{O tout dire e a autoria}

Após a leitura, põe-se a questão: quem é o responsável por essas sentenças? Somos lançados em uma experiência radical de leitura em que o texto nos chega desmoldurado. A sensação é agravada, ainda, pela ausência de travessões que, nesse caso, poderiam sinalizar a entrada do discurso direto de outrem.

Lançando mão desse procedimento, Stigger coloca em jogo duas questões que nos parecem essenciais analisar. A primeira, nos remete às palavras de Jacques Derrida que, na entrevista Essa estranha instituição chamada literatura, aponta para a paradoxalidade constitutiva do fenômeno literário: ao mesmo tempo em que seu discurso é livre para tudo dizer (tout dire), falar sobre tudo e falar qualquer coisa, ele esbarra em um inoculamento instantâneo de sua potência. O usufruto dessa amplitude conteudística se dá justamente porque tal discurso não é real, mas sim mera ficção. Todavia, se tudo é ficção, não só a própria lei não passa de uma ficção, mas também aquele discurso que abole a lei é apenas fictício, o que nos lança ao impasse desse 
tensionamento. Ao suspender a própria lei que a regimenta, a literatura configura-se como "uma instituição que tende a extrapolar [déborder] a instituição" (Derrida, 2014, p. 49).

Para Derrida, a liberdade de poder dizer tudo da literatura, em sua conformação moderna, está ligada a uma noção moderna de democracia, de liberdade de expressão, uma vez que os escritores assumem um caráter cada vez mais individualizado e, ao mesmo tempo, passam a responder por seus escritos. Nesse sentido, é possível entrever a dimensão perigosa da literatura com a qual Stigger se (nos) põe a jogar, uma vez que, ao publicar as sentenças criminosas, não está em questão o choque moral provocado em seu leitor devido ao conteúdo daquilo que lê, mas sim o abalo diante do que o gesto literário em si é capaz de provocar.

Já a segunda questão diz respeito à noção de autoria, que se agudiza em escritas que mantêm-se no fio da navalha, como é o caso de Delírio de Damasco. Há um forte apelo em torno da imagem autoral a quem, de algum modo, deve-se imputar alguma responsabilidade. Para Benveniste, a existência dos pronomes é ao mesmo tempo uma questão de língua e de linguagem, de "instâncias do discurso", isto é, "os atos discretos e cada vez únicos pelos quais a língua é atualizada em palavra por um locutor" (Benveniste, 2005, p. 277). Para o linguista:

cada $e u$ tem a sua referência própria e corresponde cada vez a um ser único, proposto como tal [...]. Eu só pode definir-se em termos de "locução", não em termos de objetos, como um signo nominal. Eu significa "a pessoa que enuncia a presente instância de discurso que contém eu" (Benveniste, 2005, p. 278).

Todavia, a autora escapa desse enrosco ao entregar nas mãos do leitor a responsabilidade pelos ditos proferidos. À ocasião da intervenção feita no Sesc, Stigger cogitou expor as frases em lâminas de metal transparente, onde seria possível aos transeuntes verem-se refletidos enquanto liam, intensificando ainda mais a sensação de autoria destes. No entanto, devido a questões orçamentárias, a ideia não foi concluída e a exibição deu-se em tapumes de madeira. Ao considerar a figura do autor não como autoridade, mas sim como dispositivo de funcionamento da obra literária, Foucault afirmou que "o sujeito que escreve despista todos os signos de sua individualidade particular; a marca do escritor não é mais do que a singularidade de sua ausência; é preciso que ele faça o papel do morto no jogo da escrita" (Foucault, 2002, p. 7, grifo nosso).

Aqui percebe-se que a proximidade entre jogo e encenação não é mera coincidência. Em francês, "jogar" e "encenar" correspondem a um só verbo (jouer), e ambas as atividades estão ligadas à ideia da mimetização. Ao lançar mão da imagem do autor como jogador que se faz de morto, Foucault não pretendia pacificar o imbróglio. A permanência deste termo da equação (o autor) para o funcionamento da literatura deve ser encarada como parte do jogo que possibilita a experiência literária. Talvez esta seja uma condição da posição do escritor no jogo da experiência literária: fingir-se de morto para não morrer, fazer do seu corpo o habitáculo possível de outros corpos, mas também abandonar a concretude de sua posição. Posteriormente quem se valeu das reflexões de Foucault para propor um outro tratamento à questão foi Agamben, em "O autor como gesto". Para o filósofo italiano, o autor é uma presença simultaneamente indelével e invisível junto à experiência literária, mas que se evidencia por sua própria ausência. Além disso, a ideia de encenação, cara à dicção stiggeriana, põe-se como motor desde o início de sua produção, sobretudo em suas duas primeiras obras, onde o elemento teatral figura desde o título - O trágico e outras comédias e Gran cabaret demenzial.

É preciso entender que nem todos estarão dispostos a jogar esse jogo, mas é a partir desses papéis que o escrito se materializa e se conforma na geologia dos corpos literários: é a partir daí que ele difere tanto daquele que diz como daquilo que é dito. No final de "A morte do autor", Barthes permuta o papel do autor como detentor dos significados pelo lugar do leitor. Nesse sentido, trata-se de uma mudança de nomenclatura e não de uma verdadeira saída para o cul-de$s a c$ da autoria e a consequente detenção dos significados de um texto. A obra continua à espera de alguém para desvendá-la. Tal impasse encontrará outra formulação em "Da obra ao texto" e, na sequência, em $O$ prazer do texto, onde sustenta-se uma equivalência entre leitor e texto. 


\section{Desmolduramento enunciativo e decontextualização}

Os primórdios da forma romance estão ligados ao desejo de verossimilhança, claramente expresso em suas escolhas discursivas - Werther apresenta-se sob a chave epistolar; Drácula, constrói-se a partir de cartas e trechos de diários; Moby Dick é o relato de um sobrevivente -, mas tal insistência é paulatinamente abandonada, até o ponto em que o desejo de verdade torna-se pastiche (pense-se na febre da auto ficção histórica e autobiografia ficcional no Brasil e América Latina durante os anos 1990 e 2000, como apontou Josefina Ludmer em Aqui América Latina - uma especulação).

Assim, se a experiência com a forma romance nos ensinou a reconhecer um mundo circunscrito pela linguagem, em Delírio de Damasco temos uma linguagem sem contorno, um desmolduramento enunciativo. Os leitores não dispõem dos referenciais básicos de ancoragem que permitem ligar os enunciados (as frases) a uma situação enunciativa (narrador, enredo, personagens e espaço). Nessa ausência restam-nos apenas os pronomes que, uma vez carentes de referências (a quem podemos atribuí-los no contexto das micronarrativas), configuram-se como postos vacantes que devem ser ocupados pelo próprio leitor. E isso, dá-se de duas formas. Resgatemos um exemplo:

Minha mãe rezava

para que $e$ uño

namorasse uma negra (Stigger, 2012, p. 34, grifos nossos).

Nesse caso, vemos que o discurso se apresenta na primeira pessoa do singular. Tal escolha - assomando-se à disposição gráfica dos poemas, divididos em versos - reforça o lugar comum do uso da primeira pessoa do singular em poesia (onde há um eu-lírico confessional e ao qual o leitor adere) e convoca os leitores, na ausência do contexto, a ocupar esses lugares pronominais a cada vez que o enunciado é performado.

Outro recurso explorado dá-se a partir do empréstimo da diç̧ão publicitária:

O ser humano

Só toma atitude

Quando fere o bolso (Stigger, 2012, p. 30).

Aqui é bom.

Só tem

homem rico (Stigger, 2012, p. 39).

Essa lagoa é ótima

Pra quem quer casar.

Basta dar três mergulhinhos (Stigger, 2012, p. 66).

Os ditos, então, configuram-se como slogans publicitários, enunciados imperativos com sujeito elocutório não identificável. A aproximação de alguns trechos do livro com certas máximas publicitárias perversas - a mais clássica continua sendo a da Coca-Cola, viva as diferenças - revela esse mecanismo perigoso da língua que (im)põe ideias em evidência ao mesmo tempo em que se omite da responsabilidade. Na publicidade, a posição do "leitor" é a da identificação ao ponto de vista proposto, mas há ainda a possibilidade de furtar-se ao texto hipnótico. Já em Delírio de Damasco, dada sua natureza literária, é impossível eximir-se de uma tomada de posição diante daquilo que é lido e a ausência da instância legisladora do autor e seus arredores relega ao leitor um amargo poder.

Tal processo de desmolduramento seria não um mero abalo descontextualizador - movimento reduzido a um contexto definido espaço-temporalmente e que é passível de "recontextualização" -, mas antes uma decontextualização (Nodari, 2015), que não prevê coincidência ou encontro, mas que, antes, enfatiza a distância entre duas temporalidades e espacialidades incomensuráveis: a da ficção e do real. Esse movimento de decontextualização, levado ao extremo, como acontece em Delírio de Damasco, poderia nos fazer pensar, equivocamente, que se trata de um texto que joga com a multiposicionalidade enunciativa - várias vozes articuladas simultaneamente - mas, de fato, o que acontece no momento da leitura é que é o leitor quem deve "dizer" as frases. E tal imputação configura-se como um dos objetivos de Stigger ao conceber a intervenção: "[m]eu plano era que o espectador, confrontado com frases que foram efetivamente ditas por outras 
pessoas, mas que talvez pudessem ser ditas por ele mesmo, fosse, ao menos idealmente, levado a refletir sobre seus próprios preconceitos" (Stigger, 2013).

Nesse sentido, podemos pensar numa espécie de "grau zero da ficção" que é, ao mesmo tempo, um "grau zero da realidade", dada a indissociabilidade dos dois polos, tal qual aventa Ludmer (2007). Nesse grau zero, a posicionalidade zero da enunciação - que não define aquele que enuncia, mas também não lega o enunciado a ninguém - aproxima-se à ideia de fonema zero, nos termos que Jakobson e Lotz formulam, recuperados por LéviStrauss em "Introdução à obra de Marcel Mauss": "um fonema zero [...] opõe-se a todos os outros fonemas do francês por não comportar nenhum caráter diferencial e nenhum valor fonético constante. Em contraposição, o fonema zero tem por função própria opor-se à ausência de fonema" (Jakobson e Lotz apud Lévi-Strauss, 2011, p. 44).

Transpondo a reflexão para pensar o "grau zero da ficção" em Stigger, temos que o zero marca, por um lado, a diferença em relação às demais posições - sejam elas empíricas, ficcionais ou estruturais (autor, personagem, leitor) - e, por outro, assinala que não se trata da mera ausência de posição. Mas isso não quer dizer que a enunciação em Delírio de Damasco abdique de um sujeito que se implique em fazê-lo (ninguém) e, muito menos, exige ser ocupada por qualquer um, na acepção corriqueira do termo, em que qualquer um nos remete à indiferença anônima. No texto de Stigger, a enunciação é feita por um sujeito qualquer, lido aqui nos termos propostos por Giorgio Agamben, que ao resgatar o étimo em latim (quolibet) nos mostra que:

a tradução corrente, no sentido de "qualquer um, indiferentemente", é certamente correta, mas, quanto à forma, diz exatamente o contrário do latim: quolibet ens não é "o ser, qualquer ser", mas "o ser que, seja como for, não é indiferente"; ele contém, desde logo, algo que remete para vontade (libet), o ser qual-quer estabelece uma relação original com o desejo (Agamben, 2013, p. 11).

Nesse sentido, uma vez que o sujeito qualquer profere em sua leitura as sentenças criminosas em Delírio de Damasco, ele adquire responsabilidade sobre seu desejo - aquilo que movimenta a leitura, tal qual formula Barthes em O prazer do texto -, e o torna agente responsivo dos ditos perigosos, uma vez que a noção de autoria não desaparece, simplesmente, mas é deslocada para o próprio leitor. Ainda assim, persistimos na investigação: quem enuncia as frases de Delírio de Damasco?

\section{Pensando os tipos de discursos}

A inquietação repousa em dois aspectos: $i$ ) a noção de autoria carece de esmiuçamento; e ii) a noção de "personagem" como lastro posicional da ficção também não se aplica à obra em análise. Para isso, acionemos algumas ideias presentes no ensaio "Poetry as fiction", de Barbara Smith, que traz uma distinção entre discurso natural e discurso fictício. Grosso modo, os enunciados naturais referem-se ao discurso falado (ou a transcrição destes) e caracterizam-se como eventos históricos, pois estão inseridos em um contexto temporal e espacial específicos; já os enunciados fictícios são aqueles cuja existência é ausente de historicidade, ou seja, jamais aconteceram, de fato, no mundo real. Sua temporalidade reside em um eterno presente das sucessivas enunciações (leituras) do texto ficcional.

À primeira vista, a distinção pode parecer estanque, mas Smith trata de aprofundá-la. Para Smith, "[q]uando vemos uma produção de Hamlet, nós não assistimos uma rainha beber veneno, mas a encenação de tal evento, sobre o qual pode-se dizer que 'ocorre' apenas ao ser assim encenado" (Smith, 1971, p. 8). Há, portanto, uma distinção evidente entre a ação empírica e sua encenação, não sendo uma mais verossímil que a outra, pois o que está em questão são dois pontos de vista distintos que se articulam no mesmo mundo: um ponto de vista factual, em que vemos um sujeito com uma taça na mão, e um ponto de vista exclusivamente "ficcional", onde o envenenamento é enunciado pelas linguagens próprias da dramaturgia.

Assim, o enunciado fictício é somente seu próprio discurso, a própria expressão em atos verbais e não seu autor, personagens ou supostos leitores. A reflexão é completamente inovadora, pois vem em consonância com os pensamentos até aqui listados acerca da morte 
do autor, que emula a imagem da experiência literária como um jogo de remissões. O que está em questão é o próprio escrito e não seus arredores. Para Smith, toda poesia seria, então, discurso mimético, mas o que é mimetizado não são os lugares, as personagens ou situações, e sim a própria enunciação. Ocorre a "fabricação de objetos e eventos fictícios dos quais há casos ou tipos possíveis ou existentes [...]. [D]izer que um artista representou certo objeto ou evento é dizer que ele construiu um membro fictício de uma classe identificável de objetos ou eventos naturais (reais)" (Smith, 1971, p. 12).

Todavia, Delírio de Damasco põe alguns impasses interpretativos ao esquema de Smith. O caráter ambíguo da autoria e da posição temporal dos enunciados, o fato de que as frases foram ouvidas e anotadas, tudo isso impossibilita o encaixe confortável em um dos dois polos de enunciação. Por um lado, pode-se lê-lo sob a chave dos enunciados naturais transcritos: são enunciados vocais transplantados para sua modalidade escrita, sem intermediações; por outro, podem ser também enunciados fictícios. Mas, justo essa modalidade de transcrição cria uma tensão em redor da autoria das frases. Poderíamos lê-las como um discurso alheio, reportado de ouvido pela autora. Mas esta inscrição histórica dos enunciados não nos diz nada. Seu contexto permanece rarefeito. Aqui, quem "se faz de morto" é a própria personagem, o que nos leva a uma hipótese algo absurda: as máximas são potencialmente proferidas por ninguém - o que já assegura um considerável mal-estar, mas, na medida em que as lemos, a falta de lastro nos faz ter de lidar com outra possibilidade, tanto mais desagradável: somos nós mesmos quem proferimos as frases.

$\mathrm{O}$ fato de que o discurso seja ficcional exime o autor de responsabilidade. $\mathrm{O}$ fato de que esse mesmo discurso é uma transcrição deveria eximi-lo ainda mais profundamente, na mesma medida em que a "responsabilidade" é transposta para a personagem ou, no caso de Stigger, para aquele a quem se ouve. Como a personagem está inscrita em uma linguagem sem contorno, como ele é, de certa forma, a própria frase, o discurso em Delírio de Damasco torna-se inimputável.

\section{Um excurso: pensando as epígrafes}

Dada a concisão do volume, os pequenos detalhes não passam desapercebidos. Nas primeiras páginas, chamam atenção as duas epígrafes, cujo teor reforçam, novamente, o que Ludmer apontou como literatura pós-autônoma, ao percebermos o entremeamento entre realidade e ficção, e, ainda, a noção de uma escrita de ouvido - nos termos propostos por Marília Librandi, que tem trabalhado com alguns autores da literatura brasileira sob o signo do audível. Em Delírio de Damasco, nos interessa pensar na possibilidade de multiplicação de vozes autorais nesses textos que advêm da escuta.

A primeira epígrafe, de Bioy Casares, diz: "[r]ecordé que entre los presagios enumerados por de Quincey está la frase casualmente oída en la calle"; e a segunda, excerto do prefácio ao romance de Oswald de Andrade, Serafim Ponte Grande, "[a] gente escreve o que ouve - nunca o que houve". Ora, o contexto dos trechos é esclarecedor. O primeiro foi retirado do diário de viagens de Casares, escrito durante sua estadia no Brasil em 1960, em que o escritor alude ao "boca a boca" das ruas como premonição do que está por vir. Ao selecioná-lo, Stigger demonstra que em Delírio de Damasco aquilo que Casares chamou de presságio participa da fabricação de realidade (Ludmer, 2013) "[a]credito que certo momento da nossa sociedade está inscrito nessa sequência de frases" (Stigger, 2013).

Para lermos a segunda epígrafe, façamos um recuo ao "Manifesto Antropófago", onde evidencia-se a importância da audição para o projeto antropofágico, que se posicionava contra o silenciamento das vozes bárbaras na escrita. A primazia do que se ouve sobre aquilo que se vêe tinha como objetivo recuperar a materialidade essencial da língua, ao despi-la de seus contornos de praxe (contexto, espaço, personagens), tal qual observa-se em Delírio de Damasco. Assim, a epígrafe ressalta o aspecto ficcional ou puramente "falsificado" daquilo que se ouve, que sempre distorce, pela perda de informação (o $h$ faltante, por exemplo), o que houve.

A escolha da citação de Oswald de Andrade assinala o alinhamento estético e político de Stigger com a tradição antropófoga, no que diz respeito à devoração produtiva das alteridades, como é o caso de Delírio de Damasco e da intervenção prévia, Pré-histórias. Stigger absorve das ruas aquilo que lhe soa producente em termos estéticos e devolve a essa mesma 
rua o resultado final de seu procedimento. Do mesmo modo, em Oswald, o jogo com a citação faz-se presente em seu projeto estético, sobretudo em obras como Memórias sentimentais de João Miramar (1924) e Pau-Brasil (1925), onde vemos, respectivamente, o diálogo entre linguagens distintas (poemas, citações, texto dramatúrgico, jornalístico) e a transcrição de trechos integrais de documentos históricos, como a carta de Caminha, acionando o procedimento dessacralizador do ready-made duchampiano a partir desse deslocamento funcional.

Assim, nota-se na composição de Delírio de Damasco um processo de transposição de registros e linguagens - da linguagem falada e das artes plásticas (não esquecer da intervenção nas ruas que o precede) -, que são extremamente caros à autora, haja vista sua formação e atuação enquanto curadora de exposições. Acompanhamos o deslocamento de objetos (nesse caso, enunciados) de seu contexto original para um outro. Se para os dadaístas do início do século XX o ready-made, valendo-se do uso de objetos extremamente funcionais em seus contextos de partida, visava combater o prescritivismo acerca do belo e mesmo a motivação do gesto artístico, cem anos depois, nas mãos da escritora brasileira, a sua atualização põe em xeque sua própria matéria-prima, a língua, e sua expressão via literatura. Põe em xeque, também, a questão da autoria; uma notória reprimenda em relação a $A$ fonte e a outras obras dadaístas é: "qualquer um faria isso". Ao mesmo tempo, esta afirmação dessacraliza a posição do artista como detentor e usuário virtuoso de meios técnicos, e dessacraliza, em última instância, a própria obra. No ready-made, a autoria torna-se quase criminosa.

\section{Desleitura e voyeurismo auditivo}

Pensar a literatura como um ato de criação (Deleuze, 2014) - ou, ainda, um movimento de resistência e de inventividade (Deleuze, 1998) - permite-nos redimensionar a esfera do delírio que dá nome à ficção de Stigger. Em sua etimologia, delirar guarda proximidade com a agricultura (de - indicando afastamento, e lira - sulco formado na terra pelo arado, onde deveriam ser lançadas as sementes) e indica justamente a ação de estar fora dos eixos, do local indicado, significa uma ruptura com o paradigma que leva ao estado de desorientado. Há, assim, uma amplificação do título que vem seguido da marca de pertencimento, de Damasco, remetendo à capital da Síria, no Oriente que, em Stigger, converte-se em desorientação enunciativa.

Indo além, e servindo-nos do mote proposto por Derrida, em $O$ monolinguismo do outro, lançamo-nos numa leitura desconstrutivista, de ouvido, que passa por outra língua (no caso, o francês), onde pensamos o delírio em seu correlato francês, délire, e daí extrairmos o ato de "desler" (dé-lire), que é o jogo proposto em Delírio de Damasco. Para Camilo Penna, em sua análise de Os anões, quando o sujeito é elidido e nos vemos diante de "um mundo literalmente sem eu", o significante do texto não pode ser pensado na disjunção mapa e território. Iser, ao comentar as relações entre jogo e experiência de leitura literária, nos aponta para o risco de questionar a razão de ser do jogo ou mesmo seus pressupostos, pois: "dar um fundamento ao jogo significaria suspender a diferença; por isso, a maneira de jogar só se manifesta na diferenciação crescente das possibilidades do jogo" (Iser, 2013, p. 347). Contudo, neste aspecto, o texto stiggeriano, ao invés de enfraquecer-se diante desses questionamentos, ganha força e potencializa-se ao alcançar seu ponto alto: a dúvida e o retesamento do tout dire derrideano. Seguindo a bricolagem etimológica e remissiva, sabemos que um dos usos obsoletos do verbo em inglês para ler, to read, era usado como sinônimo de orientar, organizar, pôr em ordem, o que endossa novamente nossa tese de uma desleitura que pretende, para além do simples dessarranjo, promover uma nova experiência - nos levando para além dos limites daquilo que estamos habituados, para prosseguir no resgate etimológico do vocábulo.

Dito tudo isso, podemos pensar Delírio de Damasco enquanto uma experiência de des-leitura que joga com o desmolduramento: o desmonte de uma cadeia de significados possíveis - a ficção paradigmática -, em lugar de um rasgo simultâneo na e da própria língua. Tal gesto violento não espera do leitor a "cooperação na criação de seus sentidos" (Smith, 1971) e muito menos leva em conta as suposições imaginadas pelo autor sobre seu público leitor. 
Até aqui falamos apenas do ponto de vista teórico e crítico, que produz e desmancha sentidos, e pouco sobre os efeitos dessa operação tal como afeta e é percebida pelo leitor. Smith resumiu a questão ao re-conhecimento evidente a respeito do artífice por trás daquilo que é lido/assistido:

Enquanto assistimos à peça, o palco recua e as identidades pessoais dos atores dão lugar àquelas das ficções que eles encenam, mas quando, na cortina final, aplaudimos, não é para Hamlet que estamos aplaudindo, mas para quem performa e ao dramaturgo em si. As ilusões da arte nunca são desilusões. A obra de arte interessa, impressiona, e nos move tanto como a coisa representada quanto como a representação em si (Smith, 1971, p. 14).

A conclusão talvez satisfaça aos exemplos escolhidos pela teórica para fundamentar sua argumentação (sonetos e peças shakespearianas). Seria a distinção entre enunciado natural e fictício a mera ciência de estar diante de um e não de outro (a informação de uma capa ou o contexto da sala de espetáculos)?

Delírio de Damasco arrebenta os finos fios da lógica proposta ao chocar os dois âmbitos - real e ficcional -, implodindo a figura guia do autor e apagando as molduras correntes da ficção. $\mathrm{O}$ fato de não se fincar em nenhum dos polos de segurança, reativa a instância perigosa da literatura apontada por Derrida. Resgatando usos arcaicos da etimologia inglesa de perigo (danger), vemos contemplado não apenas o sentido corrente, "poder de fazer mal", mas também, “aquilo que causa alterações" (Harper, s.d.). Tal recuperação semântica torna-se propositiva para pensar em Delírio de Damasco como texto que reativa as facetas deste tipo de experiência literária perigosa, uma vez que sua leitura implica em um deslocamento posicional inusual aos seus leitores.

Talvez possamos entrever em Delírio de Damasco um apelo de voyeurismo auditivo. Ao invés de delirarmos imaginando a integridade (física e subjetiva) dos corpos vistos à distância ou aos pedaços, como nos peep-shows precursores do cinema, no atrevido livreto somos convidados a uma experiência análoga, mas distinta. Dessa vez é preciso dar corpo aos enunciados fragmentários, supostamente colhidos de ouvido, desprovidos de feições para imputar-lhes os sentidos muitas vezes criminosos e indóceis. Nessa ausência aterradora, tudo indica que a máscara pode ser vestida por qualquer um, autor ou ator, inclusive nós mesmos.

\section{Referências}

AGAMBEN, Giorgio (2013). A comunidade que vem. Belo Horizonte: ed. Autêntica.

AGAMBEN, Giorgio (2007). O autor como gesto. In: AGAMBEN, Giorgio. Profanações. São Paulo: Boitempo.

BARTHES, Roland (2011). A morte do autor. Da obra ao texto. In: BARTHES, Roland. O rumor da língua. São Paulo: Martins Fontes. p. 57-64.

BARTHES, Roland (2011). Da obra ao texto. In: BARTHES, Roland. O rumor da língua. São Paulo: Martins Fontes. p. 65-75.

BARTHES, Roland (1987). O prazer do texto. São Paulo: Perspectiva.

BENVENISTE, Émile (2005). Problemas de linguística geral I. São Paulo: Pontes.

DELEUZE, Gilles (2014). O que é o ato de criação? In: DELEUZE, Gilles. Textos sobre estética. Belo Horizonte: Ed. UFMG.

DELEUZE, Gilles (1998). Lógica do sentido. São Paulo: Perspectiva.

DERRIDA, Jacques (2014). Essa estranha instituição chamada literatura. Belo Horizonte: Ed. UFMG.

FOUCAULT, Michel (2002). O que é um autor? Portugal: Veja/Passagens.

HARPER, Douglas (Org.) (s.d.). Online Etymology Dictionary. [S.1.]. On-line. Disponível em: https:// www.etymonline.com/word/danger. Acesso em: 7 jul. 2018.

ISER, Wolfgang (2013). O fictício e o imaginário. Rio de Janeiro: Ed. UERJ. 
LIBRANDI, Marília (2014). Escritas de ouvido na literatura brasileira. Literatura e sociedade, São Paulo, v. 2, n. 19, p. 131-148.

LUDMER, Josefina (2013). Aqui América Latina: uma especulação. Belo Horizonte: Ed. UFMG.

NODARI, Alexandre (2017). Quase evento: sobre a estoricidade da experiência literária. Revista eLyra, n. 10, p. 55-77, dez.

PENNA, João Camilo (2010). Veronica Stigger e a arte de dessentir. Blog da Cosac Naify, São Paulo. On-line. Disponível em: https://bit.ly/2HClnn2

SMITH, Barbara Herrnstein (1974). Poetry as fiction. In: SMITH, Barbara Herrnstein. New directions literary history. Baltimore: Johns Hopkins University Press.

STIGGER, Veronica (2012). Delírio de Damasco. Florianópolis: Cultura e Barbárie.

STIGGER, Veronica (2013). Pré-histórias: uma arqueologia poética do presente. Z Cultural, Rio de Janeiro, ano 8, n. 3. Disponível em: <http://revistazcultural.pacc.ufrj.br/pre-historias-uma-arqueologia-poeticado-presente-de-veronica-stigger/>. Acesso em: 30 jun. 2018.

LEVI-STRAUSS, Claude (2011). Introdução à obra de Marcel Mauss In: LEVI-STRAUSS, Claude. Sociologia e antropologia. São Paulo: Cosac Naify. 